\title{
Production bio-diesel from fat tail and internal organs of Iraqi sheep's in Kirkuk city.
}

\author{
Dr. Hussein H. Hamed \\ Department of Fuel and Energy, Technical College-Kirkuk, \\ Foundation of Technical Education, Iraq,
}

\begin{abstract}
This study was performed on production process of bio-diesel from fats and internal organs of sheep's in Kirkuk city, Northern of Iraq. It revealed that great proportions of the productivity of these fats in conjunctions with using different ratios of ethanol at each production process with varying temperature.

The first stage was production small samples of bio-diesel by using different parameters and conditions (the ethanol percentage additive and temperature changes) to obtain practically the largest proportion of production.
\end{abstract}

Keywords: - bio-diesel, Iraqi sheep's in Kirkuk city.

\section{INTRODUCTION}

Biodiesel refers to a vegetable oil- or animal fat-based diesel fuel consisting of long-chain alkyl (methyl, ethyl, or propyl) esters.Biodiesel is typically made by chemically reacting lipids (e.g., vegetableoil,animalfat $\left(\right.$ tallow $\left.^{[1][2]}\right)$ )withan alcohol producing fatty acid esters.

Biodiesel is meant to be used in standard diesel engines and is thus distinct from the vegetable and waste oils used to fuel converted diesel engines. Biodiesel can be used alone, or blended with petro diesel in any proportions. Biodiesel can also be used as a low carbon alternative to heating oil.

The National Biodiesel Board (USA) also has a technical definition of "biodiesel" as a mono-alkyl ester. ${ }^{[3]}$

Biodiesel sample:

Blends of biodiesel and conventional hydrocarbon-based diesel are products most commonly distributed for use in the retail diesel fuel marketplace. Most of the world uses a system known as the "B" factor to state the amount of biodiesel in any fuel mix: ${ }^{[4]}$

- $100 \%$ biodiesel is referred to as $\mathbf{B 1 0 0}$

- $20 \%$ biodiesel, $80 \%$ petrodiesel is labeled $\mathbf{B 2 0}$

- $5 \%$ biodiesel, 95\% petrodiesel is labeled $\mathbf{B 5}$

- $2 \%$ biodiesel, 98\% petrodiesel is labeled $\mathbf{B 2}$

Blends of $20 \%$ biodiesel and lower can be used in diesel equipment with no, or only minor modifications, ${ }^{[5]}$ although certain manufacturers do not extend warrantycoverage if equipment is damaged by these blends. The B6 to B20 blends are covered by the ASTM D7467 specification. ${ }^{[6]}$ Biodiesel can also be used in its pure form (B100), but may require certain engine modifications to avoid maintenance and performance problems. ${ }^{[7]}$ Blending B100 with petroleum diesel may be accomplished by:

- Mixing in tanks at manufacturing point prior to delivery to tanker truck.

- Splash mixing in the tanker truck (adding specific percentages of biodiesel and petroleum diesel).

- In-line mixing, two components arrive at tanker truck simultaneously.

- Metered pump mixing, petroleum diesel and biodiesel meters are set to $X$ total volume, transfer pump pulls from two points and mix is complete on leaving pump.

\section{PROPERTIES OF BIODIESEL}

Biodiesel has better lubricating properties and much higher cetane ratings than today's low sulfur diesel fuels. Biodiesel addition reduces fuel system wear, ${ }^{[8]}$ and in low levels inhigh pressure systems increases the life of the fuel injection equipment that relies on the fuel for its lubrication. Depending on the engine, this might include high pressure injection pumps, pump injectors (also called unit injectors) and fuel injectors.

The calorific value of biodiesel is about $37.27 \mathrm{MJ} / \mathrm{kg} .{ }^{[9]}$ This is $9 \%$ lower than regular Number 2 petrodiesel. A variation in biodiesel energy density is more dependent on the feedstock used than the production process. Still, these variations are less than for petrodiesel. ${ }^{[10]}$ It has been claimed biodiesel gives better lubricity and more complete combustion thus increasing the engine energy output and partially compensating for the higher energy density of petrodiesel. ${ }^{[11]}$

Biodiesel is a liquid which varies in color between golden and dark brown depending on the production feedstock. It is slightlymiscible with water, has a high boiling point and low vapor pressure. The flash point of 
biodiesel $\left(>130^{\circ} \mathrm{C},>266{ }^{\circ} \mathrm{F}\right)^{[12]}$ is significantly higher than that of petroleum diesel $\left(64{ }^{\circ} \mathrm{C}, 147^{\circ} \mathrm{F}\right)$ or gasoline $\left(-45^{\circ} \mathrm{C},-52{ }^{\circ} \mathrm{F}\right)$. Biodiesel has a density of $\sim 0.88 \mathrm{~g} / \mathrm{cm}^{3}$, higher than petro diesel $\left(\sim 0.85 \mathrm{~g} / \mathrm{cm}^{3}\right)$.

Biodiesel has virtually no sulfur content, ${ }^{[13]}$ and it is often used as an additive to Ultra-Low Sulfur Diesel (ULSD) fuel to aid with lubrication, as the sulfur compounds in petrodiesel provide much of the lubricity. The aim of this work is producingBio-diesel process from fat tail and internal organs of Iraqi sheep's in Kirkuk city as follows;

This process includes two stages which is Pre-treatment- Esterification \& production (transistor fiction) in which the acidic cracking fat saturated by adding concentrated sulfuric acid to it with continuous mixing. Then added ethanol to extract the sulfuric acid, remaining of broken fat and others (saturated), where notes are two layers. Upper room layer include saturated fat and sulfuric acid, ethanol and the density is less than the lower and the lower layer include fat Broken using small samples to find the optimum yield of bio-diesel from different conditions include change of temperature range and the percentage of ethanol additive.

\section{Practical Part:}

\section{Materials;}

1. Sheep fats andinternal organs of Iraqi sheep's used in the present study were collected from main slaughterhouses in Kirkuk city.

2. Ethyl alcohol obtained from local markets and its purity about $99.9 \%$ and the specific gravity is 0.789 0.790 .

3. Sodium hydroxide as a base catalyst(Scharau SO04251000 Kg 0360 Batch 11467002,M.Wt. 40).

4. Sulfuric acid obtained from local market, the purity of this acid is $98 \%$ (Sp.Gr. is 1.84) AR.

5. Glycerol $99 \%$ chem. Pure $\left(\mathrm{CH}_{2} \mathrm{OH}\right)_{2} \mathrm{CHOH}$ Mw. $=92.09$ Product code $: 15523$.

\section{Equipment:}

The equipment used in this study for both steps of pretreatment (extraction and esterification) and transesterfication steps are summarized in table(A), with their producing company and country.

Table (A), The Apparatus used and their Manufactures

\begin{tabular}{|c|c|c|c|}
\hline No. & Name of equipment & \multicolumn{2}{|c|}{ Company / origin } \\
\hline 1 & Heat flat magnetic stirrer & $\begin{array}{l}\text { Type: MR Hei-standard } \\
\text { No. :505-20000-00-3 } \\
\text { Ac2301240 V } \quad 50160 \mathrm{~Hz} \\
\text { Germany }\end{array}$ & $\begin{array}{l}\text { Ser. No. :011355160 } \\
825 \text { W } 100-140011 \mathrm{~min} .\end{array}$ \\
\hline 2 & Reflux Condenser & \multicolumn{2}{|c|}{ Germany } \\
\hline 3 & Centrifuge & $\begin{array}{l}\text { D-78532 Tuttingen } \\
\text { 208-240 V } \quad 50-60 \mathrm{~Hz} \\
\text { Zul. Drehzahl } 6000 \mathrm{Umin}\end{array}$ & $\begin{array}{l}\text { Germany } \\
0.28 \mathrm{~A} \\
\text { zul. Dichte } 1.2 \mathrm{Kg} \backslash \mathrm{dm}^{\wedge} 3\end{array}$ \\
\hline 4 & $\begin{array}{l}\text { Mercury thermometer from } 0 \text { to } \\
100^{\circ} \mathrm{C}\end{array}$ & \multicolumn{2}{|c|}{ Germany } \\
\hline 5 & 3-Neck flask $(500 \mathrm{ml})$ & Gerr & any \\
\hline
\end{tabular}

The practical procedure includes:

At the laboratory, they were melted by slowly heating up to $60^{\circ} \mathrm{C}$ and filtered in order to obtain the fat and remove gums, protein residues, and suspended particles. Thus, obtained fats were homogenous in nature, which were stored in air tight opaque plastic jars to prevent oxidation.The specific gravity of the sheep fat is 0.8772.The practical includes the following main steps;

1. Pre-treatment- Esterification.2. Production (transistor fiction).

1. Pre-treatment-Esterification:

Where they are in the process to get rid of saturated fat acid using strong sulfuric acid works to break the bonds of these fats At the same time, ethanol is used as a derived work to pull $\left(\mathrm{H}_{2} \mathrm{SO}_{4}\right)$ with non-fat broken from fat.

The stepsofPre-treatment- Esterification;

After installing the parts preparation device as shown in Fig (1) we go to the following steps; 


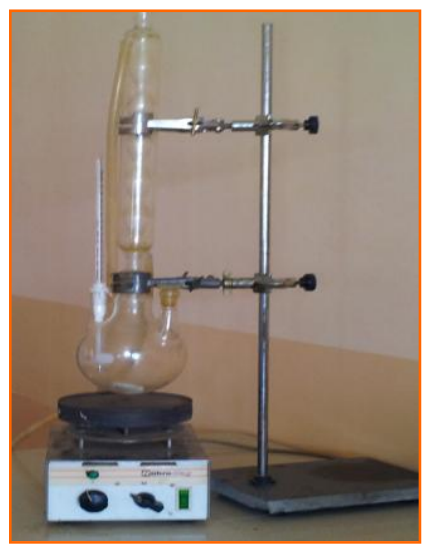

Fig (1) Apparatus for Pre-treatment-Esterification

1. We are part of the fat weight and part of the Maly of the sheep as much as $100 \mathrm{~g}$ of each part.

2. We take different amounts of ethanol at each experiment as much as $(22 \%-27 \%-35 \%-40 \%)$ of the weight of the fat and the Maly of the sheep and different temperature $57.5^{\circ} \mathrm{C}$ and $67.5^{\circ} \mathrm{C}$.

3. Sulfuric acid $\mathrm{H}_{2} \mathrm{SO}_{4}$ weigh as much as $1 \%$ of the weight of the fat and the Maly of the sheep.

4. The fat and the Maly of the sheep added to the distillation flask after dissolving them with magnetic stirrer driver and at a certain temperature

5. Ethanol is added to the mixture of fat, and after ten minutes sulfuric acid is added and left the mixture to react for half an hour within the specified temperature as shown in fig (2).

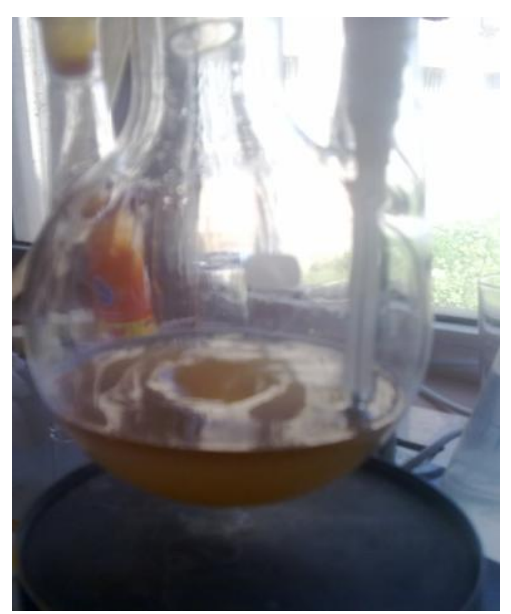

Fig (2) Ethanol adding.

Make sure the water circulation through the condenser so as not to ethanol evaporates.

6. After half an hour content is discharged to the distillation flask separating funnel to separate the sulfuric acid, ethanol and acid saturated fat unsaturated fats. Where the lower layer represents a saturated fat others because of the intensity and Upper layer represents sulfuric acid and ethanol and saturated fats, as shown in Fig (3).

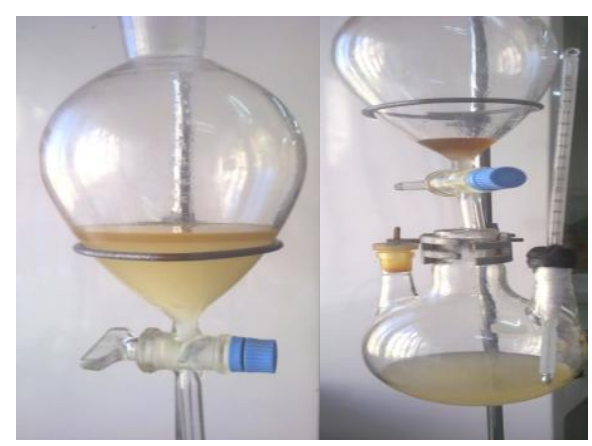

Fig (3) Upper and lower layer. 


\section{PRODUCTION (TRANSISTOR FICTION)}

Transesterification of animal fat for the production offatty acid methyl esters was carried out in the presence ofacidic and basic catalysts as shown in fig (1).

The steps of production:

1. Taken the fat that has been processed by the first process and once again due to the distillation flask and also heats up within the same range that was selected in the first operation and maintain its survival within the same range.

2. Taken a certain weight of $(\mathrm{NaOH})$ which is $1 \%$ of the weight of the fat and dissolves in ethanol which weight is equal to the weight that was used in the first operation as shown in fig (4).

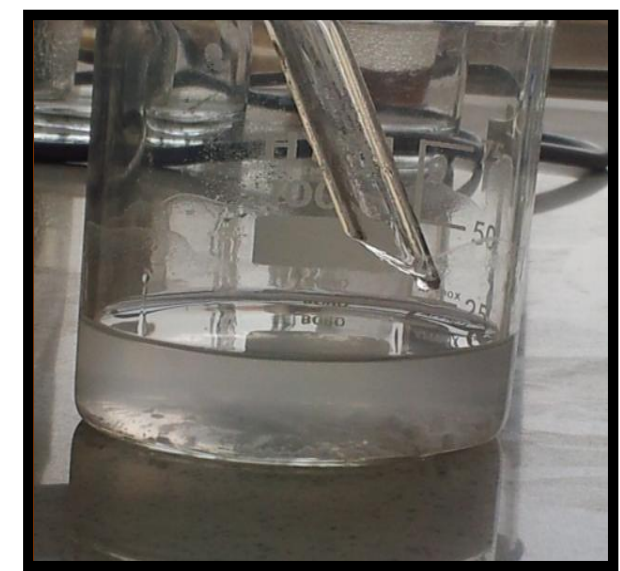

Fig (4) NaoH dissolving in ethanol.

3. Add mixture ethanol $(\mathrm{NaOH})$ to the fat and after each (10 minutes) is withdrawn sample of this fat and placed in the test tube as much as $8 \mathrm{ml}$ with $1 \mathrm{~mL}$ of glycerol and shake the tube and placed in a centrifuge for one minute and then go out is observed to be two layers layer, Upper layer bio-diesel represent and the lower layer represents glycerol as shown in fig (5).

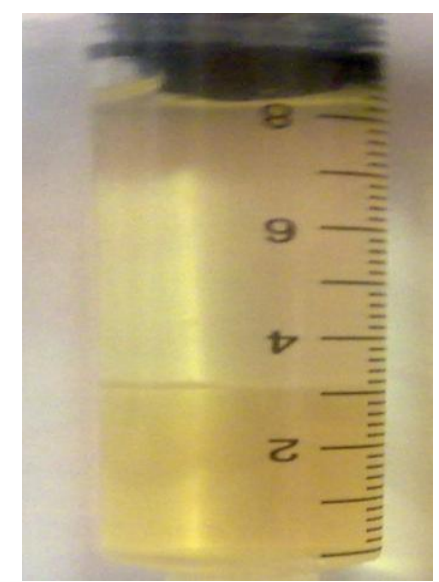

Fig(5) Bio-diesel layer and glycerol layer

The use of glycerol is very necessary is the one who puts an end to the interaction. Non-existence of it interaction to be indefinitely.

\section{RESULT AND DISCUSSION}

Through the first set of experiments the ethanol percentage is $22 \% \mathrm{wt}$ and temperature $57.5^{\circ} \mathrm{C}$ so we take four samples in the beginning after 10Min, the second sample after 20Min, the third after 30Min and the fourth after 40Min. In order to check the samples we let it at an ambient temperature for five days, then we see some part of sample frizzed due to a high proportion of non-saturated fats extracted as shown in table(1). 


\begin{tabular}{||c|c|c|c|c|c|c||c||}
\hline \hline $\begin{array}{c}\text { Time } \\
(\mathbf{m i n})\end{array}$ & $\begin{array}{c}\text { Sample } \\
(\mathbf{m l})\end{array}$ & $\begin{array}{c}\text { Glycerol } \\
(\mathbf{m l})\end{array}$ & Total & bio & fat & Product(\%) & \\
\hline 10 & 8 & 1 & 9 & 4 & 3 & 44.9 \\
\hline 20 & 8 & 1 & 9 & 4 & 3 & 44.9 \\
\hline 30 & 8 & 1 & 9 & 4 & 3 & 44.6 \\
\hline 40 & 8 & 1 & 9 & 4 & 3 & 44.9 & \\
\hline
\end{tabular}

Table (1) Ethanol wt. percentage $22 \%$ and temp. $57^{\circ} \mathrm{C}$.

It is clearly from the picture attached with table (1) the four samples freeze with general a productive percentage is $44.825 \%$.

\begin{tabular}{|c|c|c|c|c|c|c||}
\hline $\begin{array}{r}\text { Time } \\
(\mathbf{m i n})\end{array}$ & $\begin{array}{r}\text { Sample } \\
(\mathbf{m l})\end{array}$ & $\begin{array}{r}\text { Glycerol } \\
(\mathbf{m l})\end{array}$ & Total & bio & fat & Product(\%) \\
\hline 10 & 8 & 1 & 9 & 3.4 & 3 & 37 \\
\hline 20 & 8 & 1 & 9 & 3.4 & 3.2 & 37 \\
\hline 30 & 8 & 1 & 9 & 3.4 & 3 & 37.7 \\
\hline 40 & 8 & 1 & 9 & 3.4 & 3 & 37.7 \\
\hline
\end{tabular}

Table (2) Ethanol wt. percentage $27 \%$ and temp. $57^{\circ} \mathrm{C}$.

From the second experiment, shown in table(2) with it's picture also the four samples freeze with $27 \%$ ethanol wt. percentage the overall productivity was $37.77 \%$.

\begin{tabular}{||c|c|l|c|c|c|c||}
\hline $\begin{array}{l}\text { Time } \\
(\mathbf{m i n})\end{array}$ & $\begin{array}{l}\text { Sample } \\
(\mathbf{m l})\end{array}$ & $\begin{array}{l}\text { Glycerol } \\
(\mathbf{m l})\end{array}$ & Total & bio & Glycerol & Product(\%) \\
\hline 10 & 8 & 1 & 9 & 6 & 3 & 66.66 \\
\hline 20 & 8 & 1 & 9 & 6 & 3 & 66.66 \\
\hline 30 & 8 & 1 & 9 & 6 & 3 & 66.66 \\
\hline 40 & 8 & 1 & 9 & 6 & 3 & 66.66 \\
\hline
\end{tabular}

Table (3) Ethanol wt. percentage $35 \%$ and temp. $57^{\circ} \mathrm{C}$.

Through the third sample we see there is no freezing and it is clear from the attached picture and the production of bio-diesel is $66.66 \%$.

\begin{tabular}{|c|c|c|c|c|c|c|}
\hline $\begin{array}{l}\text { Time } \\
(\text { min) }\end{array}$ & $\begin{array}{l}\text { Sample } \\
(\mathrm{ml})\end{array}$ & $\begin{array}{l}\text { Glycerol } \\
(\mathrm{ml})\end{array}$ & Total & bio & fat & Product(\%) \\
\hline 10 & 8 & 1 & 9 & 5.9 & 0.2 & 62.22 \\
\hline 20 & 8 & 1 & 9 & 5.8 & 0.1 & 64.44 \\
\hline 30 & 8 & 1 & 9 & 5.7 & 0.1 & 62.2 \\
\hline 40 & 8 & 1 & 9 & 5.8 & 0.1 & 63.33 \\
\hline
\end{tabular}

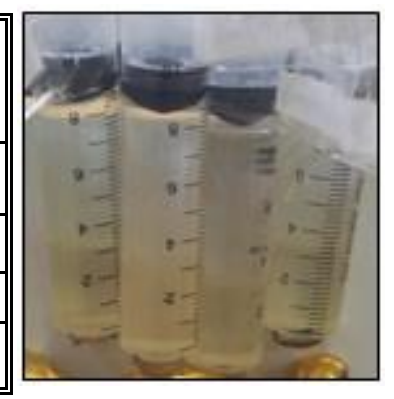


Table (4) Ethanol wt. percentage $40 \%$ and temp. $57^{\circ} \mathrm{C}$

\begin{tabular}{|c|c|c|c|c|c|c||}
\hline $\begin{array}{c}\text { Time } \\
(\mathbf{m i n})\end{array}$ & $\begin{array}{c}\text { Sample } \\
(\mathbf{m l})\end{array}$ & $\begin{array}{c}\text { Glycerol } \\
(\mathbf{m l})\end{array}$ & Total & bio & fat & Product(\%) \\
\hline 10 & 8 & 1 & 9 & 5.6 & 3.4 & 62.2 \\
\hline 20 & 8 & 1 & 9 & 5.6 & 3.4 & 62.2 \\
\hline 30 & 8 & 1 & 9 & 5.6 & 3.4 & 62.2 \\
\hline 40 & 8 & 1 & 9 & 5.6 & 3.4 & 62.2 \\
\hline
\end{tabular}

The fourth sample the average productivity is equal to $64.44 \%$.

During the results from the $4^{\text {th }}$ experiments there is an inverse proportion between the productivity and the ethanol percentage under constant temperature.

\begin{tabular}{||c|c|c|c|c|c|c||}
\hline \hline $\begin{array}{c}\text { Time } \\
(\mathbf{m i n})\end{array}$ & $\begin{array}{c}\text { Sample } \\
(\mathbf{m l})\end{array}$ & $\begin{array}{c}\text { Glycerol } \\
(\mathbf{m l})\end{array}$ & Total & bio & fat & Product(\%) \\
\hline 10 & 8 & 1 & 9 & 6.4 & 2.6 & 71.1 \\
\hline 20 & 8 & 1 & 9 & 6.35 & 2.65 & 70.55 \\
\hline 30 & 8 & 1 & 9 & 6.4 & 2.6 & 71.1 \\
\hline 40 & 8 & 1 & 9 & 6.35 & 2.65 & 70.55 \\
\hline
\end{tabular}

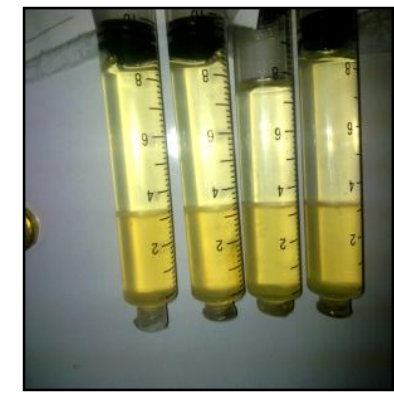

Table (5) Ethanol wt. percentage $22 \%$ and temp. $67.5^{\circ} \mathrm{C}$.

The other experiments we change the ethanol percentage with constant temperature $67.5^{\circ} \mathrm{C}$ as following;

\begin{tabular}{||c|c|c|c|c|c|c||}
\hline \hline $\begin{array}{c}\text { Time } \\
(\mathbf{m i n})\end{array}$ & $\begin{array}{c}\text { Sample } \\
(\mathbf{m l})\end{array}$ & $\begin{array}{c}\text { Glycerol } \\
(\mathbf{m l})\end{array}$ & Total & bio & fat & Product(\%) \\
\hline 10 & 8 & 1 & 9 & 5.6 & 3.5 & 64.4 \\
\hline 20 & 8 & 1 & 9 & 5.6 & 3.25 & 63.8 \\
\hline 30 & 8 & 1 & 9 & 5.6 & 3.25 & 63.8 \\
\hline 40 & 8 & 1 & 9 & 5.6 & 3.2 & 64.4 \\
\hline
\end{tabular}

Table (6) Ethanol wt. percentage $27 \%$ and temp. $67.5^{\circ} \mathrm{C}$.

The productivity of the $5^{\text {th }}$ experiment is $70.8 \%$, but quickly frozen it also clear from the attached picture with table (5).

\begin{tabular}{||c|c|c|c|c|c|c||}
\hline $\begin{array}{c}\text { Time } \\
(\mathbf{m i n})\end{array}$ & $\begin{array}{c}\text { Sample } \\
(\mathbf{m l})\end{array}$ & $\begin{array}{c}\text { Glycerol } \\
(\mathbf{m l})\end{array}$ & Total & bio & fat & Product(\%) \\
\hline 10 & 8 & 1 & 9 & 5.45 & 3.55 & 60.55 \\
\hline 20 & 8 & 1 & 9 & 5.45 & 3.55 & 60.55 \\
\hline 30 & 8 & 1 & 9 & 5.2 & 3.8 & 57.77 \\
\hline 40 & 8 & 1 & 9 & 5.45 & 3.55 & 60.55 \\
\hline
\end{tabular}

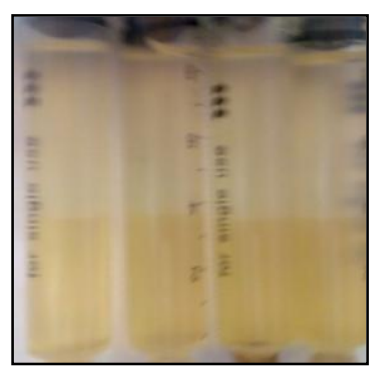

Table (7) Ethanol wt. percentage $35 \%$ and temp. $67.5^{\circ} \mathrm{C}$.

The $6^{\text {th }}$ sample the productivity was $64.1 \%$ with $27 \%$ wt ethanol and $67.5^{\circ} \mathrm{C}$. 


\begin{tabular}{|c|c|}
\hline Properties Results & Bio-Diesel \\
\hline Density at $15.6^{\circ} \mathrm{C}$ & 0.8626 \\
\hline${\text { Viscosity at } 40^{\circ} \mathrm{C}}^{\mathrm{C}}$ & 4.014 \\
\hline Water content $\%$ & Trace \\
\hline API & 32.5 \\
\hline Cetan number & 51.5 \\
\hline
\end{tabular}

Table (8) Ethanol wt. percentage $40 \%$ and temp. $67.5^{\circ} \mathrm{C}$.

The $7^{\text {th }}$ experiment, the ethanol wt. percentage was $35 \%$ and the productive was $62.2 \%$ with no freeze.

The $8^{\text {th }}$ experiment with no freeze the productivity was $59.85 \%$.

During the comparison between the 32 experiments we find the following cases;

1- The sample was frozen due to the evaporation of percent of ethanol from the hole distillation flask while adding materials and the high temperature caused ethanol evaporation as we know the boiling point of ethanol is $78 .^{\circ} \mathrm{C}$.

2- Due to the quantity and quality of bio-diesel production, the highest yield was obtained through an experiments did not happen any freeze is the third of experiment that yield was $66.66 \%$ with $35 \%$ ethanol and temperature $57.5^{\circ} \mathrm{C}$.

3- The optimum sample of bio-diesel it has the following analysis;

\section{REFERENCES}

[1] The Royal Society (January 2008). Sustainable biofuels: prospects and challenges, ISBN 978-0-85403662-2, p. 61.

[2] Gordon Quaiattini. Biofuels are part of the solution Canada.com, April 25, 2008.

[3] EPFL Energy Center (c2007). Roundtable on Sustainable Biofuels Retrieved December 23, 2009.

[4] The Royal Society (2008). p. 2.

[5] Oliver R. Inderwildi, David A. King (2009). "Quo Vadis Biofuels". Energy \& Environmental Science 2: 343. doi:10.1039/b822951c.

[6] Catherine Brahic. Hydrogen injection could boost biofuel productionNew Scientist, March 12, 2007.

[7] The Royal Society (2008). p. 2 \& 11.

[8] Andrew Williamson. Cambodian Research Centre for Development (c2005). Biofuel: A Sustainable Solution for Cambodia? .

[9] Toxic jatropha Shrub Fuels Mexico's Biodiesel Push/2009.

[10] www.treehugger.com/files2008/65/jatropha-planting-ycatan-mexico-biodisesl.

[11] More to noxious weed fuel than meets the sky January 05, 2009.

[12] Branching out into Biodiesel - Courier Mail August 09, 2008. 